\title{
A yellow-head-like virus from Penaeus monodon cultured in Australia
}

\author{
K. M. Spann ${ }^{1,2,3, *}$, J. A. Cowley ${ }^{2,3}$, P. J. Walker ${ }^{2,3}$, R. J. G. Lester ${ }^{1,3}$ \\ ${ }^{1}$ Department of Parasitology, The University of Queensland, Brisbane 4072, Australia \\ ${ }^{2}$ CSIRO Tropical Agriculture, Private Bag No. 3, Indooroopilly 4068, Australia \\ ${ }^{3} \mathrm{Co}$-operative Research Centre for Aquaculture, Australia
}

\begin{abstract}
A rod-shaped, gill-associated virus (GAV) was found to be associated with mortalities of cultured adult Penaeus monodon from 4 farms in Queensland, Australia, from January to June 1996. Infected prawns were observed swimming at the surface and edges of ponds and displayed varying degrees of red body colouration. The lymphoid organs of infected prawns appeared disorganized, were devoid of normal tubule structure and contained highly eosinophilic areas which corresponded to foci of highly infected and necrotic cells. Rod-shaped, enveloped virions and helical nucleocapsids were identified in lymphoid organ and gill cells. Nucleocapsids were $166-435 \mathrm{~nm} \times 16-18 \mathrm{~nm}$ and enveloped virions were $183-200 \mathrm{~nm} \times 34-42 \mathrm{~nm}$. GAV isolated from infected prawns collected from 3 farms was successfully transmitted to healthy adult $P$. monodon, resulting in mortality from 7 to $8 \mathrm{~d}$ postinoculation. Mortality also occurred in prawns infected experimentally with GAV derived from lymphoid organs and gills. The morphology and cytopathology of GAV closely resemble that observed for lymphoid organ virus (LOV) from Australia and yellow-head virus (YHV) from Thailand. Molecular data are required to determine the phylogenetic relationships and appropriate taxonomic classification of these 3 prawn viruses
\end{abstract}

KEY WORDS: Electron microscopy · Penaeus monodon · Transmission · Virus

\section{INTRODUCTION}

At least 13 virus types of cultured penaeids have been described worldwide and most have been associated with disease (Lightner 1996). White spot baculovirus (WSBV) and yellow-head virus (YHV) have caused massive production losses of cultured Penaeus monodon in Thailand and elsewhere throughout Asia. Yellow-head disease was first noted by Limsuwan (1991). Infected adult prawns displayed yellow colouration of the dorsal carapace and swam slowly near the edges of ponds. Mass mortalities were observed by the third day after the appearance of clinical disease (Chantanachookin et al. 1993). Electron microscopy of lymphoid organ and hepatopancreatic interstitial cells revealed rod-shaped, enveloped virions in the cytoplasm of infected cells. Analysis of nucleic acid isolated from purified YHV suggested that it is a RNA virus.

•E-mail: kirsten.spann@tag.csiro.au
Based on the morphological characteristics of the virus particles, it has been suggested that YHV may be a member of the Rhabdoviridae or Coronaviridae (Wongteerasupaya et al. 1995).

Two other thabdo-like viruses have been described from penaeid prawns. Rhabdovirus of penaeid shrimp (RPS) has been isolated from Penaeus stylirostris and $P$. vannamei from the Americas (Lu et al. 1991). Although RPS replicates in the lymphoid organ and causes enlargement and cytoplasmic changes, infected prawns show no gross signs of disease (Nadala et al. 1992). Lymphoid organ virus (LOV) is a rod-shaped, enveloped virus which appears to be endemic in cultured P. monodon in Australia (Spann et al. 1995). Rod-shaped virions and filamentous nucleocapsids of LOV were identified in the cytoplasm of infected lymphoid organ cells but there has been no evidence that it is associated with disease.

The virus described in this paper, which we have called gill-associated virus (GAV), shares histological 
and cytopathological features with YHV and LOV Although clinically distinct from yellow-head disease, GAV is also highly pathogenic for Penaeus monodon.

\section{MATERIALS AND METHODS}

Histology. Between 10 and 20 diseased adult Penaeus monodon (5.7 to $18.8 \mathrm{~g}$ ) were collected from 2 farms in north Queensland (farms $A$ and $B$ ) and 2 farms in southeast Queensland (farms C and D). The carapace length, wet weight and external appearance of all prawns were recorded prior to fixing for light microscopy and transmission electron microscopy (TEM). The cephalothorax of each prawn was separated from the abdomen and split longitudinally. One longitudinal section was fixed in Davidson's fixative and processed for histology. Sections were stained with haemotoxylin and eosin (H\&E; Humason 1968).

Portions of the lymphoid organ, gills, hepatopancreas, heart, epidermis midgut and nerve cord were dissected from the remaining half of each cephalothorax, diced, and fixed in $2.5 \%$ glutaraldehyde $/ 2 \%$ paraformaldehyde in cacodylate buffer. Tissues were post-fixed in $1 \%$ osmium tetroxide, dehydrated through a graded series of ethanol concentrations and mounted in Spurr's resin (Spurr 1969). Sections were cut at $50 \mathrm{~nm}$, mounted on Cu-200 copper grids, stained with uranyl acetate $/ 70 \%$ methanol and Reynold's lead citrate and viewed at $80 \mathrm{kV}$ under a Jeol 1010 TEM. For each organ examined by TEM, the percentage of cells containing virions and/or nucleocapsids was recorded for 10 grid divisions of 5 tissue sections. The average percentage of cells infected was then calculated for each organ.

Source material for transmission of GAV. Following the identification of GAV in prawns from the 4 farms investigated, 18 live prawns (15.8 to $32.8 \mathrm{~g}$ ) were collected from each of 3 farms $(A, C$ and $D)$. Cephalothoraces of 3 prawns from each farm were fixed and processed for light microscopy and TEM to confirm GAV infection. The remaining cephalothoraces were snap frozen on dry ice and stored at $-70^{\circ} \mathrm{C}$ for transmission experiments. Healthy prawns used in the transmission experiments were collected from a farm in southeast Queensland which had no prior history or evidence of viral disease. Three healthy prawns were examined by light microscopy and TEM before each experiment to identify any existing viral infections.

General inocula preparation and transmission procedures. Frozen lymphoid organs, gills and whole cephalothoraces were thawed in a $37^{\circ} \mathrm{C}$ water bath. All tissues and subsequent preparations were kept at $4{ }^{\circ} \mathrm{C}$ or on ice. The carapace and calcareous mouth parts were removed from the cephalothoraces (gnathotho- races) prior to homogenization. All tissues were diluted in a 6 -fold volume of lobster haemolymph medium (LHMi Paterson \& Stewart 1974) and, unless otherwise specified, homogenized using an Ultra-turrax tissue grinder (Janke and Kunkel, Ika-werx, GmbH and Co., Staufen) either for 1 min or until a smooth homogenate was prepared. Homogenates were clarified at $1300 \times g$ in a Beckman TJ-6 table-top centrifuge for $5 \mathrm{~min}$ at $4^{\circ} \mathrm{C}$, and the supernatants futher clarified at $18000 \times g$ for 20 min at $4^{\circ} \mathrm{C}$. Supernatants below the lipid layer were removed and divided into $1 \mathrm{ml}$ aliquots. A small portion $(5 \mu \mathrm{l})$ of each preparation was negatively stained with $2 \%$ sodium phosphtungstic acid ( $\mathrm{pH}$ 6.8) and examined for viral particles by TEM.

Each experimental prawn was inoculated with $5 \mu \mathrm{l}$ suspension per $g$ body weight into the second abdominal segment using a 25 -gauge needle. Two groups of prawns were kept as negative controls for each experiment, one of which was inoculated with LHM according to weight. Prawns were examined each day and external appearance and mortality recorded. Portions of the lymphoid organ, gills, heart, hepatopancreas and epidermis of each sampled prawn were processed for TEM.

Transmission of GAV from farmed prawns. In the first experiment, viral inoculum was prepared from 5 gnathothothoraces (20.2 g) of prawns collected from farm A in north Queensland. Three $1 \mathrm{ml}$ aliquots were passed through $0.45 \mu \mathrm{m}$ filters to remove bacterial contaminants. Forty-two healthy prawns (8 to $10 \mathrm{~g}$ ) were divided into 6 equal groups. Two groups of prawns were inoculated with the filtered suspension and 2 groups were inoculated with the unfiltered suspension. Two prawns from each treatment were sampled $8 \mathrm{~d}$ post-inoculation (p.i.) and processed for light microscopy and TEM. One control prawn and another inoculated with unfiltered inoculum that remained alive at Day 14 p.i. were fixed for examination by light microscopy and TEM.

In the second transmission experiment, inocula were prepared from infected gnathothoraces (approximately $7 \mathrm{~g}$ ) from the 2 farms in southeast Queensland (C and D). Experimental prawns (25 to $40 \mathrm{~g}$ ) were divided into 8 groups of 6 . Three groups were inoculated with each of the 2 unfiltered suspensions. One prawn from each group was sampled for light microscopy and TEM at Days 11 and 14 p.i.

Transmission of GAV from lymphoid organ and gill tissue. Two experiments were undertaken to determine whether infectious GAV was present in the gills and lymphoid organs of diseased prawns. In Expt 1, an inoculum was made from 2 stored cephalothoraces (6 g) from farm A and injected into 25 healthy Penaeus monodon weighing approximately $30 \mathrm{~g}$ each. Six 
prawns were kept as negative controls. Eleven of the prawns that remained alive at $5 \mathrm{~d}$ p.i. were dissected and the gills and lymphoid organs removed, pooled and snap frozen. Portions of the lymphoid organ and gills of 4 of these prawns were fixed for light microscopy and TEM. Two control prawns were also processed for light microscopy and TEM. The cephalothorax of 1 inoculated prawn was snap frozen whole.

In Expt 2, viral inocula were prepared from lymphoid organs, gills and the whole gnathothorax of infected prawns from Expt 1. Inocula were also prepared from tissues of healthy prawns collected from a farm in southeast Queensland and snap frozen 6 mo earlier. Inocula were prepared as described above. Healthy and infected gnathothorax tissue was homogenized using the Ultra-turrax. Gills of GAV-infected ( $3 \mathrm{~g})$ and uninfected ( 4 g) prawns were ground in LHM using the Ultra-turrax, then further homogenized using a handheld glass Dounce homogenizer. GAV-infected $(0.9 \mathrm{~g})$ and uninfected $(0.38 \mathrm{~g})$ lymphoid organs were homogenized using the Dounce homogenizer. Live prawns, weighing 16 to $20 \mathrm{~g}$ were divided into 14 groups of 6 . Two replicate groups of prawns were injected with each of the 6 preparations.

Mortalities were recorded each day and 1 prawn from each group was sampled at Day 5 p.i. The gills and lymphoid organs of these prawns was examined for GAV by light microscopy and TEM.

\section{RESULTS}

\section{Natural GAV infections}

Penaeus monodon prawns sampled from 4 farms in Queensland showed signs of disease including lethargy, lack of appetite and swimming near the surface and edges of the pond. Prawns from 1 farm in north Queensland had a distinctive dark red body colour. Prawns from the other 3 farms displayed degrees of pink to red colouration, primarily of the appendages, tail fan and mouthparts. Gills of all the prawns were yellow to pink in colour. Prawns from all 4 farms had barnacle and tube worm attachment, tail rot and gill fouling by ciliates and detritus from the edges of the ponds.

\section{Light microscopy}

Sixty percent of the lymphoid organs from diseased prawns sampled from the 4 farms displayed disorganization and loss of normal, defined tubule structure (Fig. 1). Of each affected lymphoid organ 60 to $100 \%$ contained areas where the tubule structure was dis-

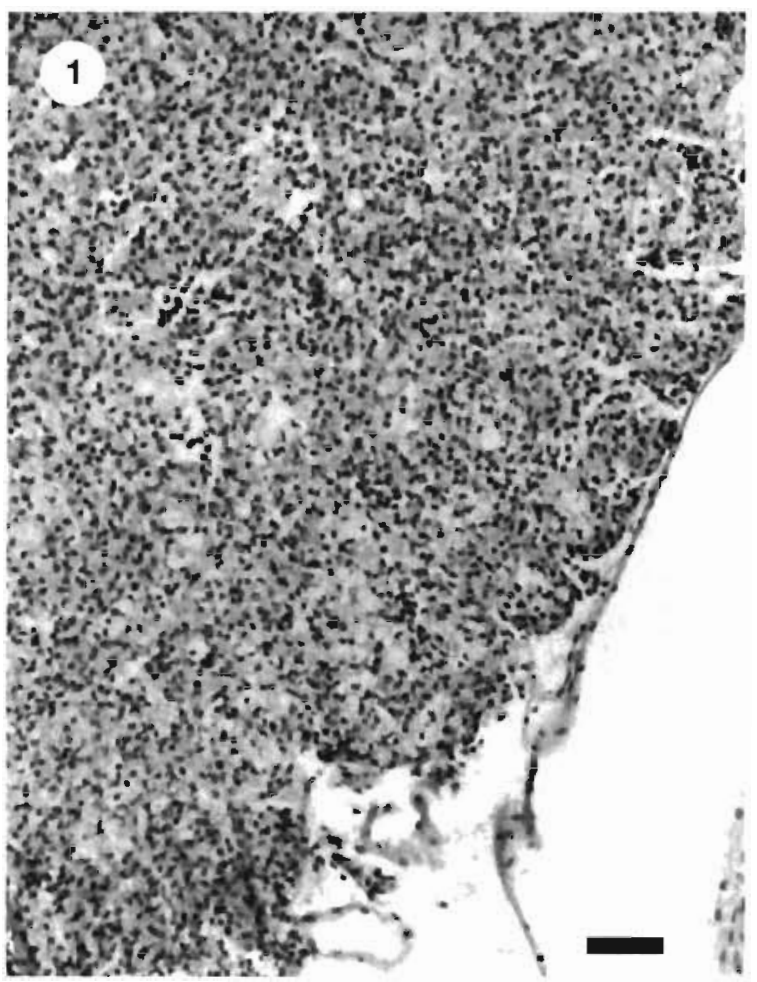

Fig. 1. Penaeus monodon infected with GAV. Lymphoid organ, showing disorganization and loss of defined, normal tubules. $H \& E$ stain. $B a r=20 \mu \mathrm{m}$

rupted. Within these areas there was no obvious cellular or nuclear hypertrophy, pyknotic nuclei or vacuolization. In association with loss of tubule structure, $32 \%$ of the lymphoid organs also had foci of abnormal cells similar to those seen in LOV-infected prawns (Spann et al. 1995), but smaller and more numerous. Defined, darkly eosinophilic foci were observed in $13 \%$ of the lymphoid organs (Fig. 2).

The gills of diseased prawns displayed structural damage such as fusion of gill filament tips, general necrosis and loss of cuticle from primary and secondary lamellae. The cytology of the gills appeared normal apart from small basophilic foci of necrotic cells. The hepatopancreas, nerve cord, heart, midgut and epidermis appeared normal in all the prawns sampled.

\section{Electron microscopy}

Rod-shaped, enveloped virus particles and filamentous material resembling viral nucleocapsids were observed by TEM in the cytoplasm of lymphoid organ cells of all the diseased prawns. In areas of tubule disruption and cellular necrosis, between 80 and $100 \%$ of the cells contained nucleocapsids which appeared to vary in length from 166 to $435 \mathrm{~nm}$, but were uniform in 


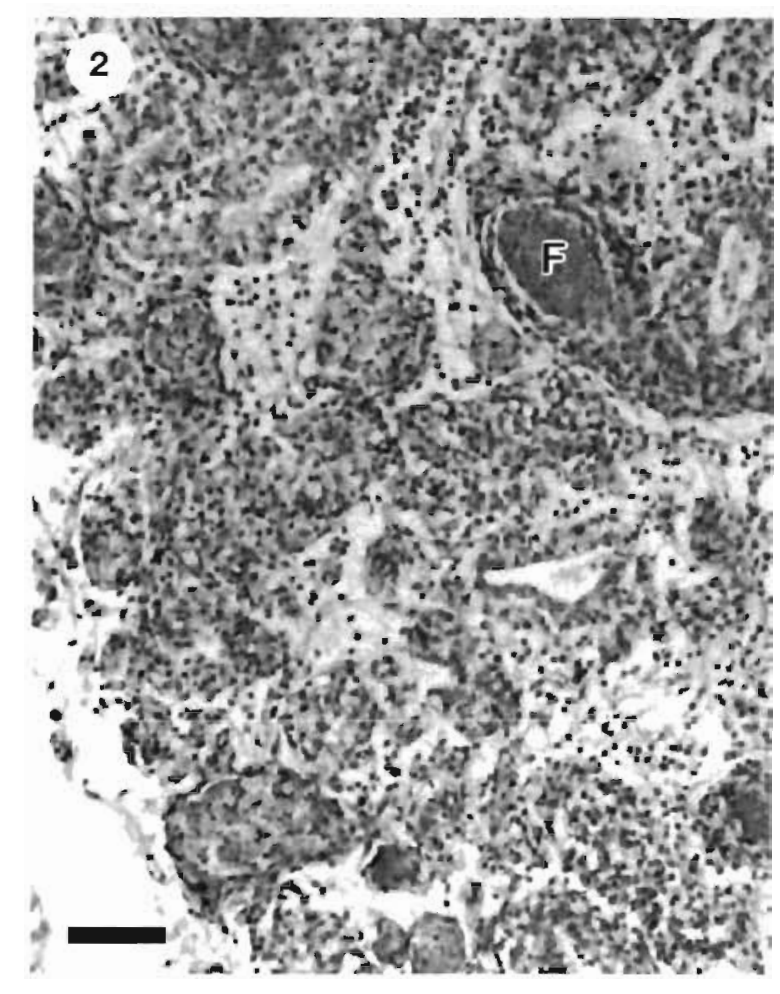

Fig 2. Penaeus monodon infected with GAV. Lymphoid organ, showing defined, darkly eosinophilic foci of necrotic cells (F). $\mathrm{H} \& \mathrm{E} . \mathrm{Bar}=4 \mu \mathrm{m}$

width from 16 to $18 \mathrm{~nm}$. Viral nucleocapsids were scattered primarily throughout the cytoplasm, although some were contained within vesicles. Cells that were heavlly infected with nucleocapsids often appeared 'empty' with degenerate cellular components (Fig. 3) Virogenic stroma were seen in some infected lymphoid organ cells. Nucleocapsids had striations (Fig. 4) with a periodicity of approximately $7 \mathrm{~nm}$ and were often observed in association with the distended endoplasmic reticulum (Fig. 5), and less commonly with fragments of host membranes.

Enveloped virions were observed in fewer than $20 \%$ of the lymphoid organ cells within areas of tubule disruption in all prawns sampled. Enveloped virions were 183 to $200 \mathrm{~nm}$ long, 34 to $42 \mathrm{~nm}$ wide and were usually enclosed either tightly (Fig. 6) or loosely (Fig. 7) within vesicles apparently formed by budding of nucleocapsids through the endoplasmic reticulum. The number

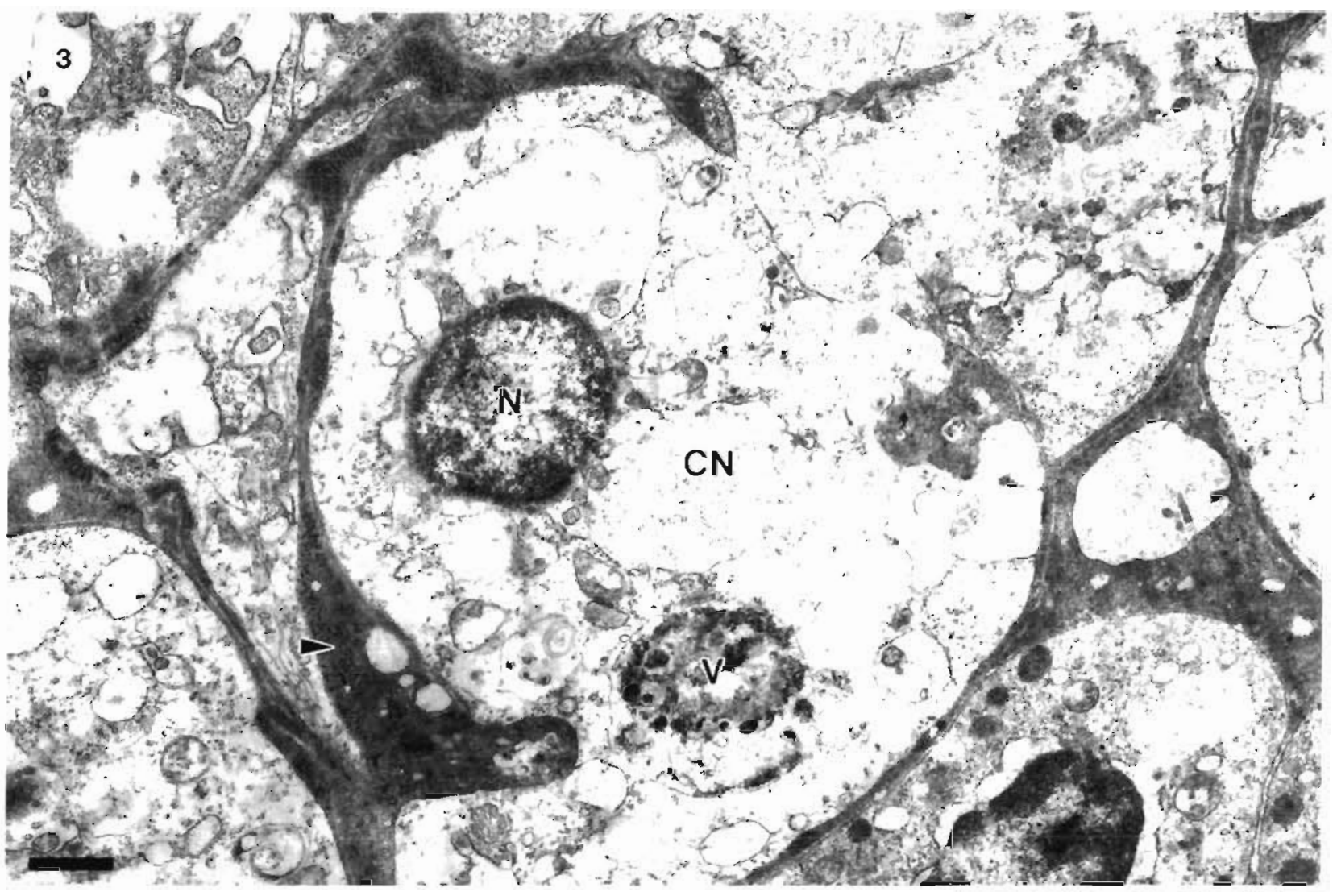

Fig. 3 Penaeus monodon infected with GAV. A lymphoid organ cell containing a virogenıc stroma (V) and showing severe cellular necrosis (CN) Enveloped virions (arrowhead) are present within the intercellular spaces surrounding this cell. N: nucleus. $\mathrm{Bar}=1 \mu \mathrm{m}$ 


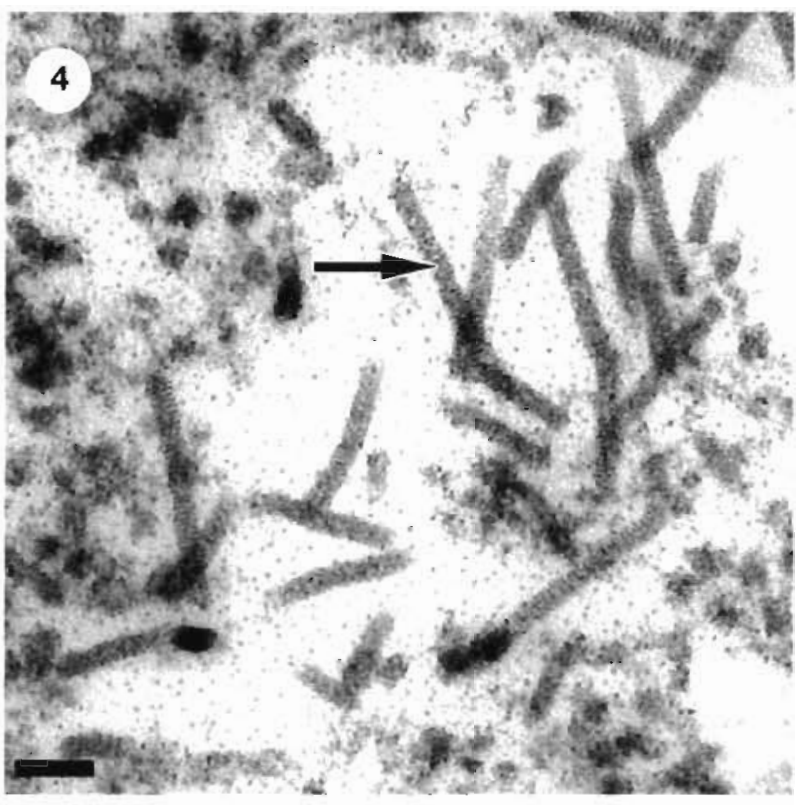

Fig. 4. Penaeus monodon. Striated (arrow) GAV nucleocapsids free in the cytoplasm of a lymphoid organ cell. Bar $=50 \mathrm{~nm}$

of virions within an array ranged from 3 to 20 . The interstitial spaces of highly infected lymphoid organs appeared to be abnormally distended (Fig. 8) and contained virions released by rupture of the plasma membrane (Fig. 9). In addition, virions were often observed associated with the intact plasma membranes of adjoining cells.

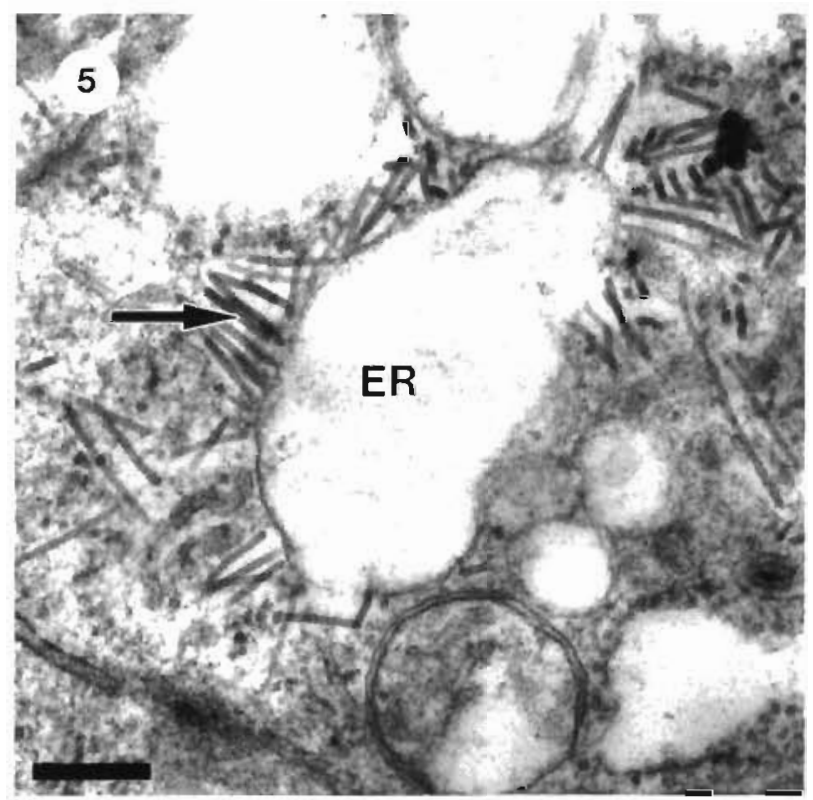

Fig. 5. Penaeus monodon. GAV nucleocapsids (arrow) in association with the endoplasmic reticulum (ER) of a lymphoid organ cell. $\mathrm{Bar}=80 \mathrm{~nm}$

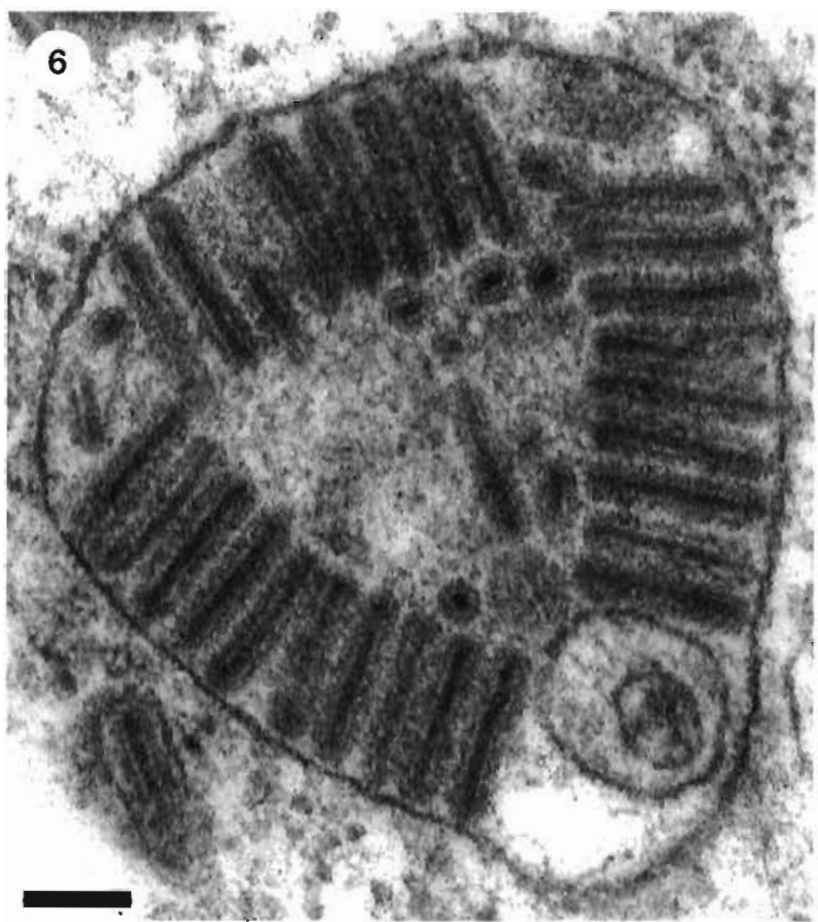

Fig. 6. Penaeus monodon. An array of GAV virions enclosed within a vesicle in a lymphoid organ cell. $B a r=80 \mathrm{~nm}$

Dark, highly eosinophilic areas seen by light microscopy (Fig. 2) corresponded to defined foci of phagocytic and necrotic cells (Fig. 10). The necrotic cells had lost their normal cell components and the phagocytes were filled with nucleocapsids and enveloped virions. Small, singular vesicles of enveloped virions were rarely observed in heart, epidermal, hepatopancreatic and midgut epithelial cells.

Enveloped, rod-shaped virions and filamentous nucleocapsids were seen in the gills of all prawns sampled from the 4 farms. Forty to $70 \%$ of gill cells contained nucleocapsids while only approximately $5 \%$ of cells contained enveloped virions. Nucleocapsids and enveloped virions occurred free in the cytoplasm and were identical in size and morphology to those in the lymphoid organ.

\section{Transmission of GAV}

Stored stocks of GAV-infected material from 3 farms in Queensland were confirmed by TEM to contain high levels of viral particles. Healthy Penaeus monodon used in the transmission experiments were infected with low levels of LOV, as confirmed by light microscopy and TEM. At no time were viral particles of any kind identified in the gills of negative control prawns. 


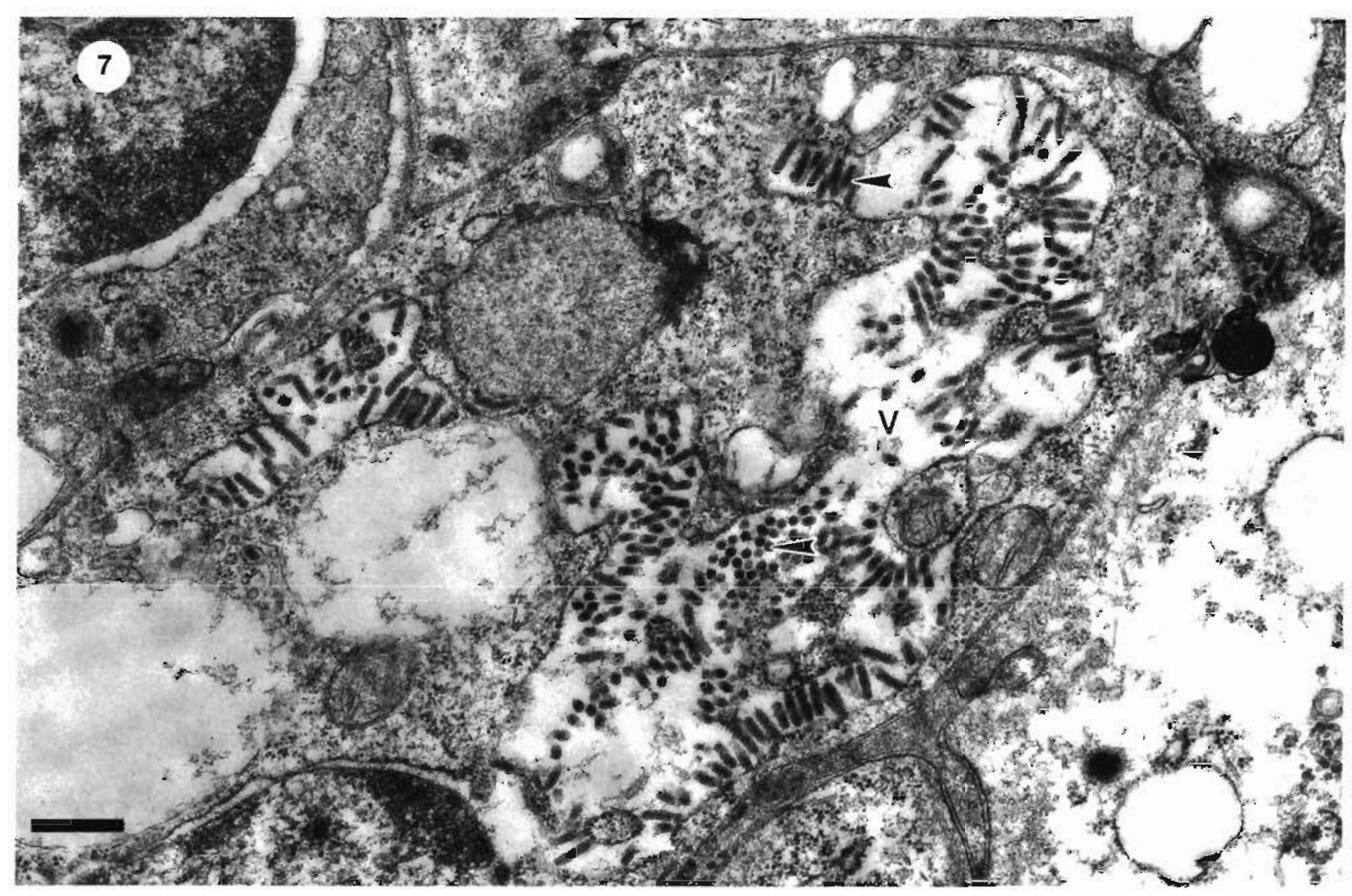

Fig. 7. Penaeus monodon. GAV virions (arrowheads) loosely and randomly enclosed in a large vacuole (V) in the cytoplasm of an infected lymphoid organ cell. Bar $=200 \mathrm{~nm}$

\section{Transmission of GAV isolated from Penaeus monodon farmed in Queensland}

Prawns inoculated with a viral suspension from prawns collected from farm A died 8 to $14 \mathrm{~d}$ p.i. (Fig. 11). The mortality curves of prawns inoculated with filtered and unfiltered viral suspensions were similar. Gross signs of disease were not evident until $7 \mathrm{~d}$ p.i., when infected prawns ceased feeding and moulting and developed pink tail fans, appendages and mouthparts. Only 1 infected prawn remained alive at Day 14 p.i. and it was pink in all body parts. The lymphoid organs of infected prawns sampled at Days 8 and 14 p.i. showed histopathology that was typical of GAV infection and included loss of defined tubule structure and the presence of darkly eosinophilic foci.

The lymphoid organs of prawns inoculated with filtered and unfiltered preparations and fixed at Day 8 p.i. showed some plasma membrane disruption and extensive cellular necrosis by TEM. Most cells (80 to $100 \%$ ) in areas where tubule structure was lost contained viral nucleocapsids and enveloped virions in cytoplasmic vesicles. The interstitial spaces contained free, enveloped virions. Infection levels were lower in the gills, where only 5 to $43 \%$ of the cells contained nucleocapsids. By Day 14 p.i., little virus was observed in the lymphoid organ of the remaining infected prawn although cellular necrosis was severe and extensive. The majority ( 80 to $100 \%$ ) of gill cells were infected with nucleocapsids, while approximately $20 \%$ of epidermal cells contained vesicles of enveloped virions aligned along the external cell boundaries (Fig. 12).

In the second experiment, using inocula from prawns collected from farms C and D, mortalities occurred 8 to $16 \mathrm{~d}$ p.i (Fig. 13). After 8 d, infected prawns displayed pink gills, appendages, tail fans, mouthparts and junctions between the cephalothorax and abdomen. Prawns ceased feeding and moulting by Day 14 p.i. They were pink to red in all body parts and the lymphoid organs contained areas of tubule disruption typical of GAV

Examination by TEM of the lymphoid organs and gills of infected prawns sampled at Days 8 and 14 p.i. confirmed that GAV from prawns collected from both farms could be transmitted to healthy Penaeus monodon prawns. Approximately $50 \%$ of the lymphoid 


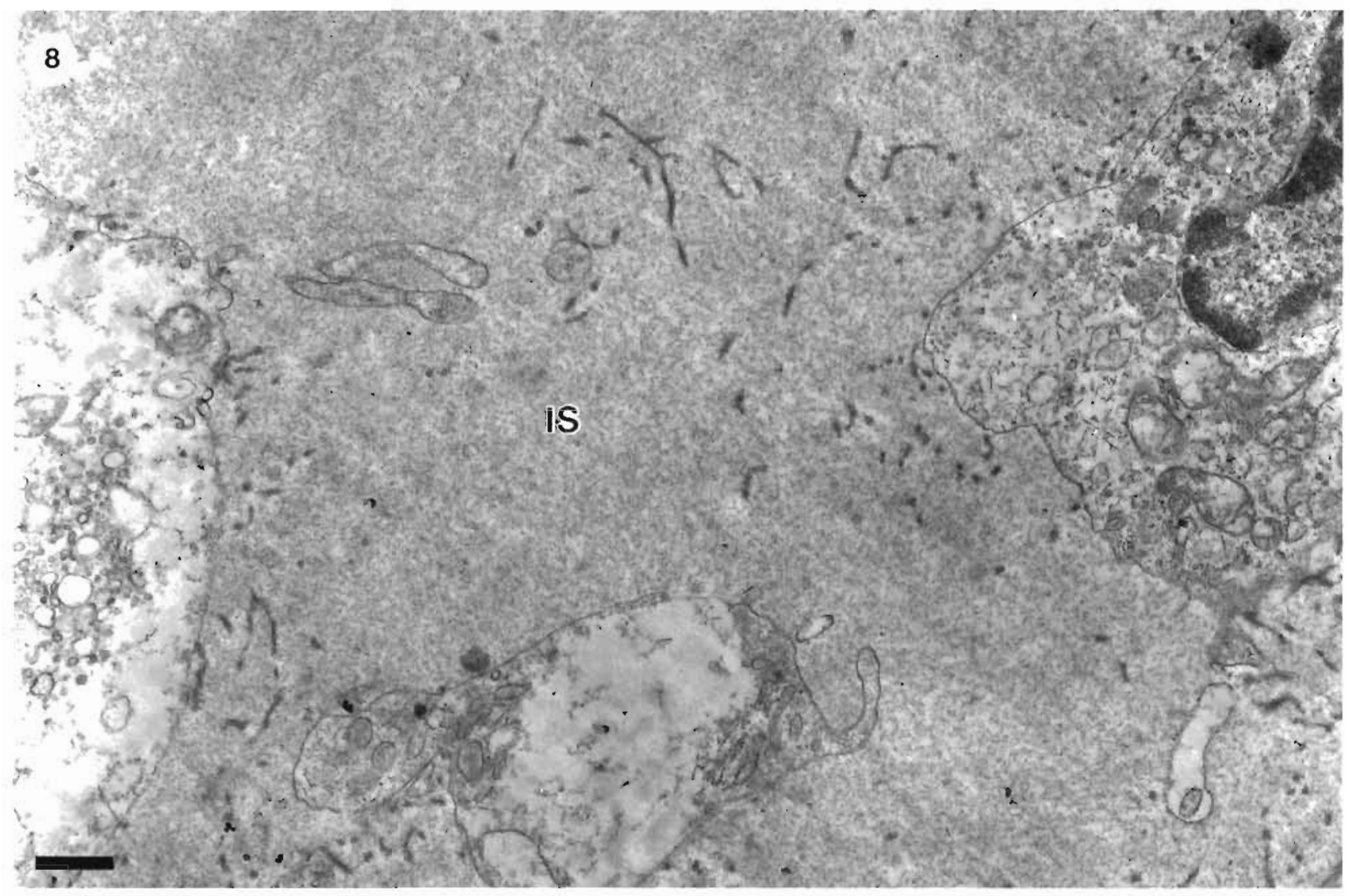

Fig 8 Penaeus monodon infected with GAV. Abnormally distended interstitial spaces (IS) within the lymphoid organ Bar $=800 \mathrm{~nm}$

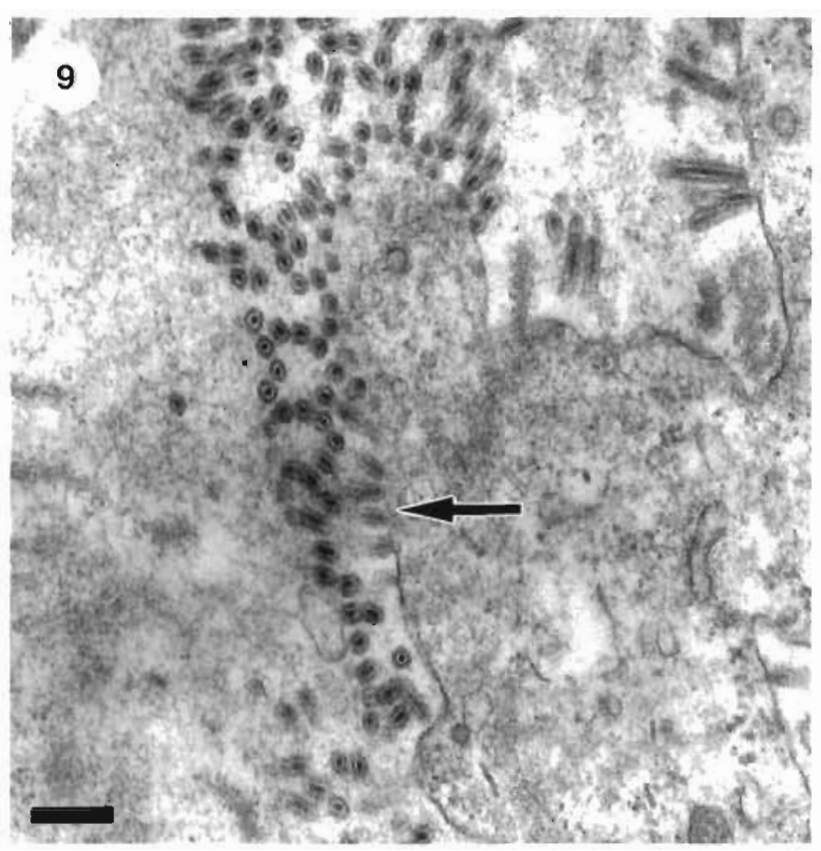

Fig 9. Penaeus monodon. GAV vinons released into the interstitlal spaces of a lymphold organ, by rupture of the plasma membrane of unfected cells (arrow). Bar $=300 \mathrm{~nm}$ organ cells of all prawns sampled at Day 8 p.l. contained scattered nucleocapsids and numerous vesıcles of enveloped virions while $5 \%$ of gill cells contanned enveloped virions. For the prawn sampled at Day 14 p.l., fewer $(30 \%)$ lymphord organ cells but more $(10 \%)$ gill cells contaıned GAV partıcles.

\section{Transmission of GAV from lymphoid organ and gill tissues}

The successful transmission of GAV from gnathothorax tissue in Expt 1 was confirmed by TEM at Day 5 p.i. The majority ( 90 to $100 \%$ ) of lymphoid organ cells and 10 to $25 \%$ of gill cells of the 4 prawns investigated were infected with nucleocapsids and enveloped virions.

In Expt 2, mortalities among prawns inoculated with GAV extracts occurred 1 to 9 d p.1. (Fig 14), while, with the exception of uninfected gill tissue, sıgnificant mortalities did not occur among prawns inoculated with tissue suspensions from healthy prawns. The reason for the mortalities immediately following inoculation with uninfected gill extracts is not known, but they 


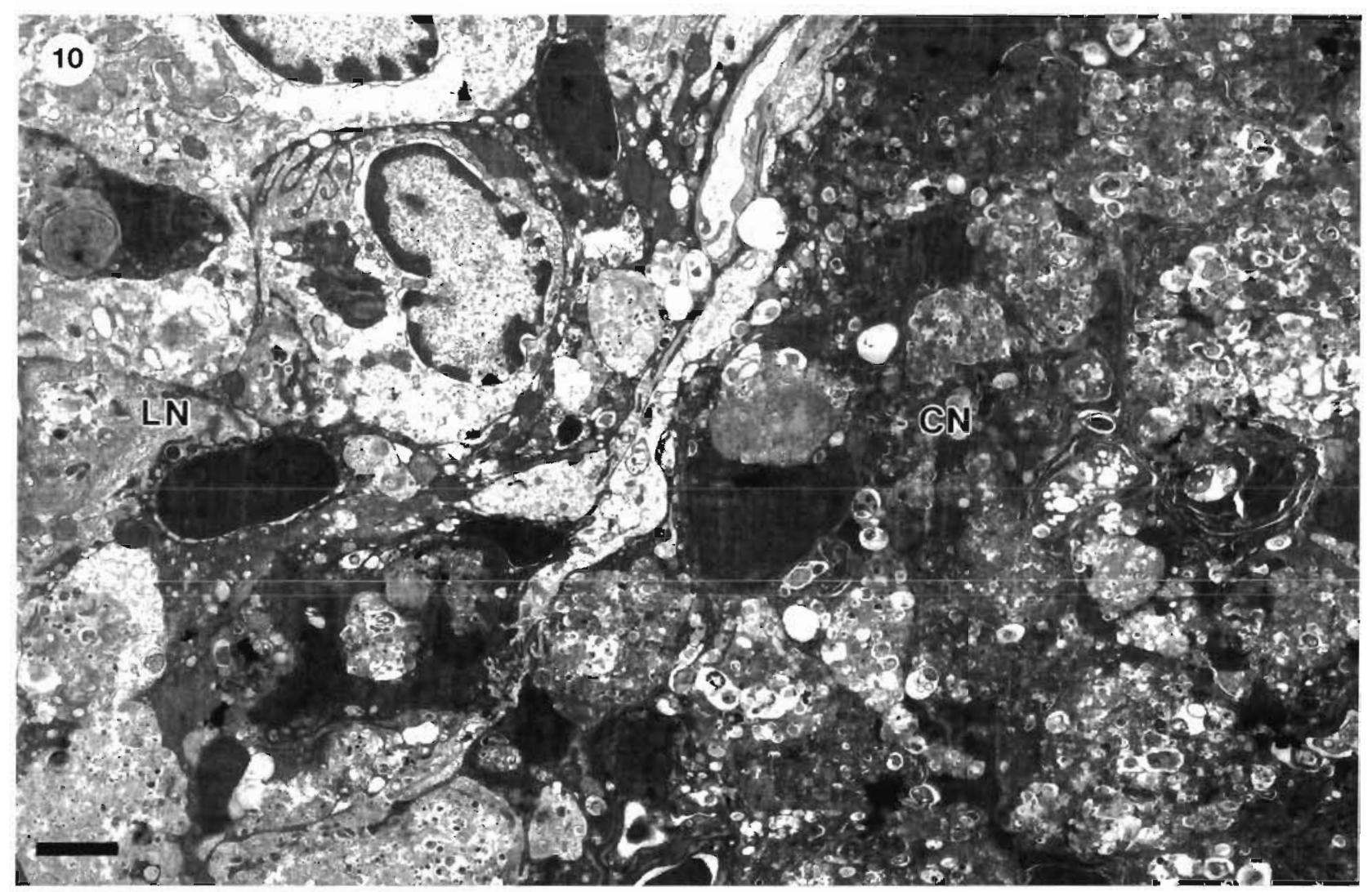

Fig. 10 Penaeus monodon infected with GAV. A defıned region of cellular necrosıs (CN) and phagocytic cell invasion within the lymphoid organ. Cells outside the focus are less necrotic (LN). Bar $=2 \mu \mathrm{m}$

may have resulted from shock due to the presence of toxic agents in this inoculum. Deaths resulting from inoculation of GAV extracts from lymphoid organ, gill and whole gnathothorax were similar, with prawns developing pink gills and red bodies by $9 \mathrm{~d}$ p.r. Light microscopy revealed lymphoid organ histopathology typical of GAV infection. TEM revealed that all in- oculated prawns, irrespective of the GAV extract used, were heavily infected (50 to $100 \%$ lymphoid organ cells and 10 to $50 \%$ gill cells for all prawns investigated). For control prawns inoculated with tissues from healthy prawns, LOV particles were detected in low levels in 2 to $10 \%$ of lymphoid organ cells but not in gill cells.

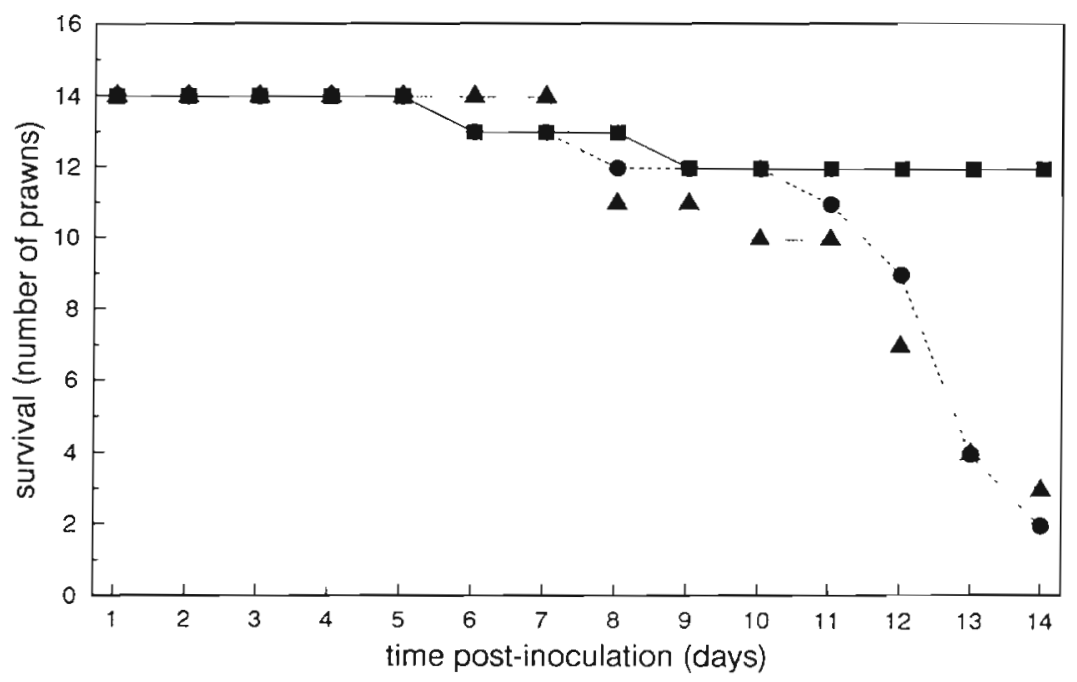

Fig 11. Penaeus monodon. The mortality of prawns inoculated with filtered and untultered suspensions of GAV isolated from whole gnathothoraces of diseased P. monodon from farm A. Mortality of control prawns either untreated or injected with lobster haemolymph medium (LHM) were combined. (ㄴ) Control; $(\bullet-\cdots)$ filtered preparathon; ( $\mathbf{A} \cdots \mathbf{\Delta}$ ) ) unfiltered preparation 


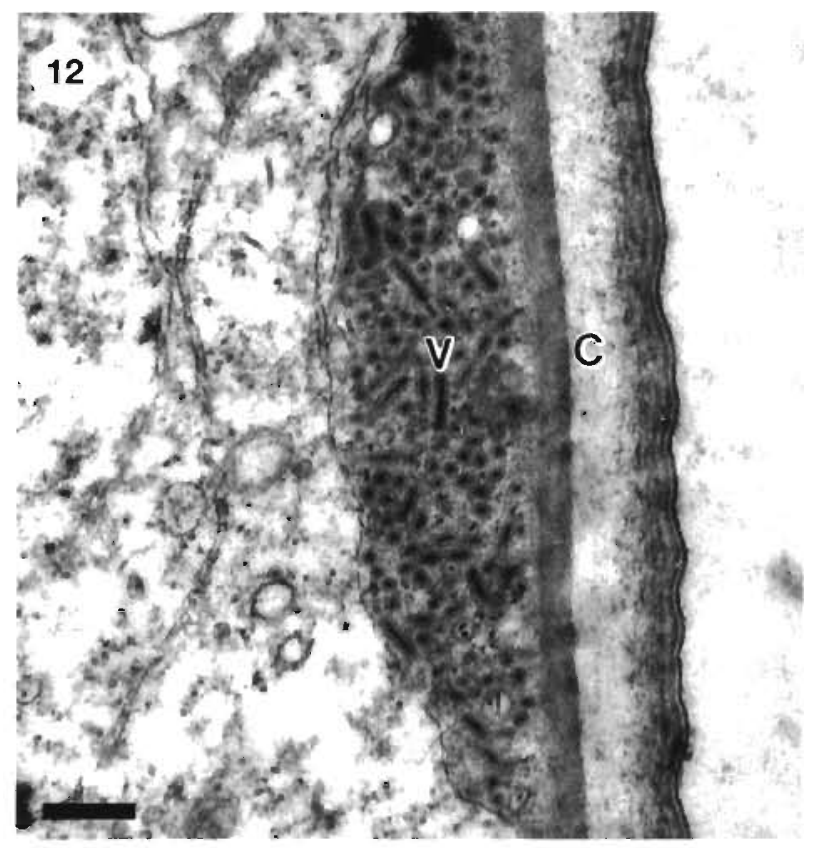

Fig. 12. Penaeus monodon. GAV virions (V) tightly packed under the carapace in the gills $14 \mathrm{~d}$ after inoculation with a suspension of GAV. C: cuticle. Bar $=200 \mathrm{~nm}$

\section{DISCUSSION}

The induction of gross signs of disease, such as red colouration, lethargy, poor appetite and mortality in healthy prawns exposed to filtered homogenates of diseased Penaeus monodon gnathothoraces indicates that farm mortalities which occurred in Queensland between January and July 1996 were caused by a virus. TEM of naturally and experimentally infected prawns revealed a rod-shaped, enveloped virus which we have named gill-associated virus (GAV). Experimental transmission showed that GAV was present in the lymphoid organs and gills of diseased prawns.

Fig. 13. Penaeus monodon. Mortality of prawns injected with GAV isolated from whole gnathothoraces of diseased $P$. monodon from farms $C$ and $D$ together with combined mortality rates for the untreated and LHM-injected control prawns. ( $* *$ ) Control; $(\bullet-\cdots)$ farm $C_{i}(\square \cdots)$ farm D

Fig. 14. Penaeus monodon. Mortality of prawns from Expt 2, injected with lymphoid organ, gill or whole gnathothorax tissue extracts from either healthy or GAV-infected prawns. Results for the 2 control groups are pooled. (**) Control; ( $* \ldots$...) healthy gills; $(\square \square)$ healthy LO; $(\triangle--\triangle)$ healthy gnathothorax; (-...) GAV-inf. gills; ( …m) GAV-

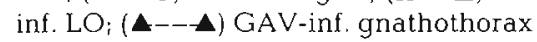
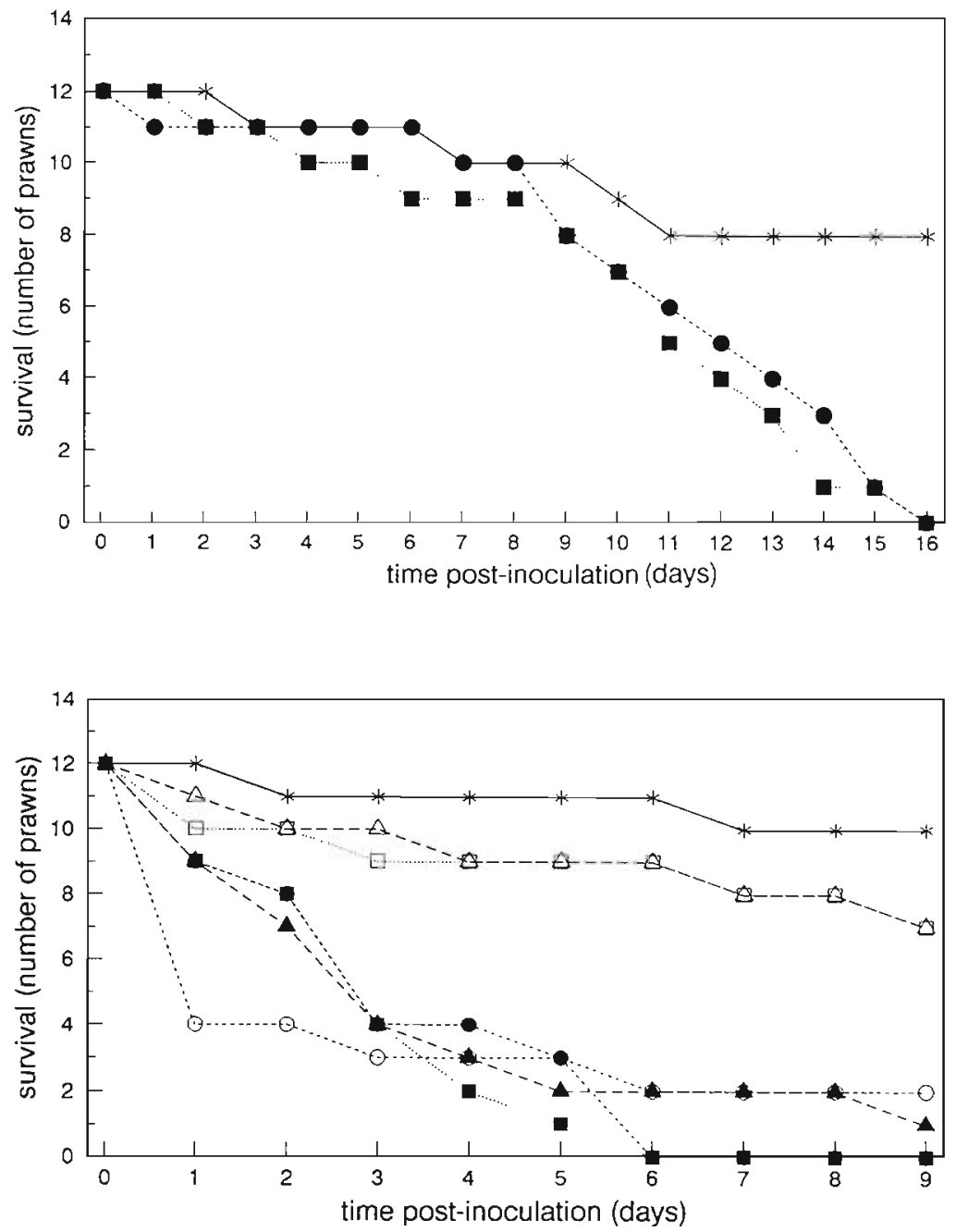
The morphology of the viral particles suggests that GAV is more closely related to the Rhabdoviridae than any other family of viruses. Enveloped virions are similar in length (100 to $430 \mathrm{~nm})$, although narrower than other rhabdoviruses (34 to $42 \mathrm{~nm}$ for GAV; 45 to $100 \mathrm{~nm}$ for Rhabdoviridae). GAV nucleocapsids (16 to $18 \mathrm{~nm}$ ) are also narrower than other known rhabdoviruses (30 to $70 \mathrm{~nm}$; Wunner et al. 1995), but possess cross-striations of helical symmetry typical of rhabdoviruses (Brun 1991). The periodicity of these crossstriations is larger than the average for rhabdoviruses (4.5 to $5 \mathrm{~nm}$; Wunner et al. 1995). Budding of nucleocapsids through the endoplasmic reticulum and the replication and accumulation of virus within the cytoplasm, as observed for GAV, is typical of RNA viruses, including rhabdoviruses (Brun 1991).

GAV is similar to LOV of Australia and YHV of Thailand in ultrastructure and cytopathology (Chantanachookin et al. 1993, Boonyaratpalin et al. 1994). YHV and LOV also infect Penaeus monodon juveniles and young adults and invade the lymphoid organ. YHV and GAV differ from LOV in that they also invade the gills. Paracrystalline arrays of YHV (Chantanachookin et al. 1993), LOV and GAV virions have been observed within the cytoplasm of lymphoid organ cells, although they appear to be more common for YHV and LOV than for GAV. Enveloped virions of GAV are similar in size to those of LOV (Spann et al. 1995) and YHV (Chantanachookin et al. 1993). Abundant filamentous nucleocapsids are common within the cytoplasm of lymphoid organ cells infected with GAV, LOV (Spann et al. 1995) and YHV (Chantanachookin et al. 1993)

The process of viral envelope aquisition by budding through the endoplasmic reticulum and the collection of virions into subsequently formed vesicles are typical of GAV, LOV and YHV. The size of the vesicles, the number of enclosed virions and the density of packing varies widely for GAV, as it does for YHV (Chantanachookin et al. 1993) and LOV (Spann et al. 1995). Free virions have been observed in the intercellular spaces of lymphoid organs infected with GAV and YHV (Boonyaratpalin et al. 1994).

Degradation of cytoplasmic components, leaving a cell which appears 'empty' apart from a nucleus and viral particles, has also been observed in lymphoid organs infected with YHV (Boonyaratpalin et al. 1994). Abnormal histology of GAV-infected lymphoid organs, including extensive tubule disruption and the formation of highly eosinophilic areas, has not been recorded for any other prawn virus.

LOV differs from YHV and GAV in having no association with disease and martality. The gross signs of disease in prawns infected with GAV were primarily nonspecific, although lethargy and swimming close to the surface at the edges of ponds have been observed also for Penaeus monodon stocks suffering from yellowhead disease in Thailand (Limsuwan 1991). Red body colouration, as observed in prawns infected with GAV, has not been recorded in association with YHV, but has been recorded for $P$. japonicus prawns infected with a white spot syndrome baculovirus (Takahashi et al. 1994). Chantanachookin et al. (1993) found that not all prawns infected with YHV displayed yellow discolouration of the cephalothorax. Colour changes are not a reliable indication of viral infection and cannot be used to differentiate viruses.

The gills of prawns infected naturally and experimentally with GAV suffered similar structural damage and cellular necrosis as prawns infected with YHV (Boonyaratpalin et al. 1994). The aggregation of virions within cytoplasmic vesicles of gill cells has also been recorded for YHV (Boonyaratpalin et al. 1994).

There was no evidence to suggest that the virus observed in the lymphoid organs of GAV-infected prawns was different to that observed in the gills, as virus particles from both tissue types appeared to be morphologically identical and cause mortality in prawns infected experimentally. The lower percentage of gill cells containing GAV particles, as compared to lymphoid organ cells of naturally infected prawns, indicates that the gills might not be the primary site of replication. Rod-shaped virions were also observed in the haemolymph and other organs, suggesting that GAV may be systemic at some stage of its development. TEM on experimentally infected prawns suggests that viral replication initiates in the lymphoid organ and progresses to the gills in later stages of the infection cycle.

Boonyaratpalin et al. (1994) recorded that cumulative mortalities among Penaeus monodon adults infected experimentally with YHV reached $100 \%$ within $3 \mathrm{~d}$ for prawns injected with gill extracts and $5 \mathrm{~d}$ for prawns injected with lymphoid organ extracts. Cumulative mortality reached $100 \%$ within $6 \mathrm{~d}$ for both tissue types in our experiments. Further studies are needed to determine whether there are differences in the relationship between virus titre and onset of mortality for GAV and YHV.

Differences in histopathology and clinical disease between prawns infected with LOV only and prawns infected dually with LOV and GAV suggest that GAV and LOV are distinct viruses. Evidence presented here also suggests that GAV is closely related to YHV in morphology and several aspects of disease pathology. GAV, LOV and YHV may be members of a complex of closely related viruses; however, the phylogenetic relationships and definitive taxonomic classification of these viruses await their characterization at a molecular level. 


\section{LITERATURE CITED}

Boonyaratpalin S, Supamattaya K, Kasornchandra J, Direkbusaracom S, Aekpanithanpong U, Chantanachookin C (1994) Non-occluded baculo-like virus, the causative agent of yellow-head disease in the black tiger shrimp (Penaeus monodon). Gyobyo Kenkyu 28(3):103-109

Brun G (1991) Rhabdoviridae, Chap 17. In: Adams JR, Bonami JR (eds) Atlas of invertebrate viruses. CRC Press, Boca Raton, FL, p 443-460

Chantanachookin C, Boonyaratpalin S, Kasornchandra J, Sataporn D, Ekpanithanpong U, Supamataya K, Sriurairatana S, Flegel TW (1993) Histology and ultrastructure reveal a new granulosis-like virus in Penaeus monodon affected by yellow-head disease. Dis Aquat Org 17: $145-157$

Humason GL (1968) Animal tissue techniques. WH Freeman and Co, San Francisco

Lightner DV (ed) (1996) A handbook of shrimp pathology and diagnostic procedures for diseases of cultured penaeid shrimp. World Aquaculture Society, Baton Rouge

Limsuwan C (1991) Handbook for cultivation of black tiger prawns. Tansetakit Co Ltd, Bangkok

Lu Y, Nadala ECB, Brock JA, Loh PC (1991) A new virus isolated from infectious hypodermal and hematopoietic necrosis virus (1HHNV)-infected penaeid shrimps. J Virol Methods 31:189-196

Editorial responsibility: Timothy Flegel,

Bangkok, Thailand
Nadala ECB, Lu Y, Loh PC, Brock J (1992) Infection of Penaeus stylirostris (Boone) with a rhabdovirus isolated from Penaeus spp. Gyobyo Kenkyu 27(3)143-147

Paterson WD, Stewart JE (1974) In vitro phagocytosis by hemocytes of Amencan lobster (Homarus americanus). $J$ Fish Res Bd Can 31:1051-1056

Spann KM, Vickers JE, Lester RJG (1995) Lymphoid organ virus of Penaeus monodon from Australia. Dis Aquat Org $23: 127-134$

Spurr AR (1969) A low viscocity epoxy resin embedding medium for electron microscopy. J Ultrastruct Res 26:31-43

Takahashi $Y$, Itami T, Kondo M Maeda M. Fujii R, Tomonaga S, Supamattaya K, Boonyaratpalin S (1994) Electron microscopic evidence of bacilliform virus infection in Kuruma shrimp (Penaeus japonicus). Fish Pathol 29(2): $121-125$

Wongteerasupaya C, Sriurairatana S, Vickers JE, Akrajamorn A, Boonsaeng V, Panyim S, Tassanakajon A, Withyachumnarnjul B, Flegel TW (1995) Yellow-head virus of Penaeus monodon is an RNA virus. Dis Aquat Org 22:45-50

Wunner WH, Calisher CH, Dietzgen RG, Jackson AO, Kitajima EW, Lafon M, Leong JC, Nichol S, Peters D, Smith JS, Walker PJ (1995) Rhabdoviridae. In: Murphy FA, Fauquet CM, Bishop DHL, Ghabrial SA, Jarvis AW, Martelli GP. Mayo MA, Summers MD (eds) Virus taxonomy, Sixth Report of the International Committee on Taxonomy of Viruses. Springer-Verlag, Vienna, p 275-288

Submitted: January 29, 1997; Accepted: July 18, 1997 Proofs received from author(s): November 26, 1997 